\title{
The testimony of the spirit, the decline of Calvinism, and the origins of restoration rational religion
}

Article

Accepted Version

Cromartie, A. (2021) The testimony of the spirit, the decline of Calvinism, and the origins of restoration rational religion. Journal of Ecclesiastical History, 72 (1). pp. 71-94. ISSN 14697637 doi: https://doi.org/10.1017/S0022046920000068 Available at https://centaur.reading.ac.uk/87556/

It is advisable to refer to the publisher's version if you intend to cite from the work. See Guidance on citing.

To link to this article DOI: http://dx.doi.org/10.1017/S0022046920000068

Publisher: Cambridge University Press

All outputs in CentAUR are protected by Intellectual Property Rights law, including copyright law. Copyright and IPR is retained by the creators or other copyright holders. Terms and conditions for use of this material are defined in the End User Agreement.

www.reading.ac.uk/centaur

\section{CentAUR}


Central Archive at the University of Reading

Reading's research outputs online 
The testimony of the spirit, the decline of Calvinism, and the origins of Restoration rational religion

\begin{abstract}
:
The mid-seventeenth century turn to moralism in English Protestant theology - exemplified here by 'Ignorance' in Bunyan's Pilgrim's Progress - involved a clear rejection of the Calvinistic doctrine of the 'internal testimony' of scripture. The upshot was the emergence of a religious impulse that emphasised the salience of a 'rational account' of scripture's credibility. The shift is conventionally traced through Richard Hooker, William Chillingworth, and the Cambridge Platonists. Hooker was, however, more Calvinist and Chillingworth more Laudian than has been recognised. The Cambridge Platonists and their 'latitudinarian' successors emerged from and were shaped by puritan culture.
\end{abstract}

Wordcount: 9413

In the later pages of Part One of Bunyan's Pilgrim's progress (1678), Christian and his friend Hopeful are dogged by Ignorance, a 'very brisk Lad' ${ }^{1}$ who comes into the road from the country of Conceit. Ignorance is a specimen of a familiar type: the cheerfully Pelagian 'civil' or 'moral man' repeatedly encountered in godly literature. ${ }^{2}$ At his first encounter with Christian, he boasts that 'I know my Lords will and I have been a good Liver: I pay every man his own; I Pray, Fast, pay Tithes and give Alms. ${ }^{3}$ Readers of Bunyan's Grace abounding to the chief of sinners (1666) might have recalled that Bunyan had himself been 'a brisk talker' during the superficially religious period preceding his authentic religious conversion. ${ }^{4}$

Ignorance is, then, a stock character. But he is not without sophistication. At his second encounter with Christian, he hotly denies that 'I am such a fool, as to think God can see no 
further then I; or that I would come to God in the best of my performances', recognising instead that 'I must believe in God for justification.' Elaborating on this point, he gives a surprisingly careful confession of his faith:

I believe that Christ died for sinners, and that I shall be justified before God from the curse, though his gracious acceptance of my obedience to his Law. Or thus, Christ makes my Duties that are Religious, acceptable to His Father by vertue of his Merits, and so shall I be justified. ${ }^{5}$

Ignorance thus retains the Reformation principle that it is Christ and Christ alone who merits justification; under cover of insistence on this Protestant position, he has, however, departed from Reformed theology in treating God's acceptance of man's obedience as the defining moment of the justifying process.

In doing so, he was in line with academic fashion. The Calvinistic Oxford theologian Thomas Tully complained that this reliance on the merits of Christ's works (as opposed to a reliance upon the works themselves) was 'the chief and most crowd-pleasing (popularis) refuge of all our Enemies'. ${ }^{6}$ As Bunyan knew, however, this popular manoeuvre had only fairly recently become available to mainstream English Protestant opinion; it was, after all, incompatible with any natural reading of the Church of England's Article XIII, which held that works performed before justification were 'not pleasant to God' and had 'the nature of sin'.7 Down to the end of James's reign, a broad-based theological consensus - supported, for example, by Lancelot Andrewes - had held that it was Christ's works as imputed to the sinner - not man's works as supported by Christ's merits - that were the 'formal cause' of justification. ${ }^{8}$ Bunyan was just re-stating this old-fashioned orthodoxy when he made Christian tell a shocked and baffled Ignorance that

true Justifying Faith puts the soul (as sensible of its lost condition by the Law) upon flying for refuge unto Christs righteousness: (which righteousness of his is not an act of grace, by which he maketh for Justification, thy obedience accepted with God, but his personal obedience to the Law, in doing and suffering for us, what that required at our hands). ${ }^{9}$ 
Bunyan was well aware, of course, of the anxiety that typically motivated the new attitudes: Ignorance is made to side-step the theology involved by pointing to the threat of antinomian excesses, 'for what matter how we live, if we may be Justified by Christs personal righteousness from all, when we believe it?' Christian replies, as might have been expected, that 'Ignorance is thy name and thou also art ignorant of the true effects of saving faith in this righteousness of Christ ${ }^{10}$ (that is, of the better behaviour that is the consequence of the completed act of justification). On Bunyan's account of the matter, the same kind of anxiety was readily provoked when unconditional saving grace was framed as saving knowledge. Hopeful is made to follow up on Christian's exposition with an enquiry about revelation: 'Ask him if he ever had Christ revealed him from Heaven'. Ignorance is immediately hostile: 'What!' he says, 'are you a man for revelations!' He is not appeased by Hopeful's supporting argument that 'Christ is so hid in God from the natural apprehensions of all flesh, that he cannot by any man be savingly known, unless God the Father reveals him to them', which he describes as 'but the fruit of distracted braines'. ${ }^{11}$

Here too, he was attacking an important element of what had previously been the orthodox position. The point that is at issue between Ignorance and Hopeful is whether an authentic (as opposed to a delusory and temporary) conversion requires, on God's side, a special act of revelation. Their exchange should be read in the light of the passage in Grace abounding where Bunyan records that his mentor, the Baptist John Gifford,

made it much his business to deliver the People of God from those false and unsound rests that by Nature we are prone to take and make to our Souls; he pressed us to take special heed that we took not up any truth upon trust, as from this or that or another man or men, but to cry mightily to God that he would convince us of the reality thereof, and set us down therein by his own Spirit in the holy Word; for, said he, if you do otherwise, when temptations come, if strongly, you not having received them with evidence from Heaven, will find you want that help and strength now to resist, as once you thought you had. ${ }^{12}$

Thus the evidence from heaven is scriptural evidence; though truths must be received from God, they must be picked out by the spirit in the holy word; the tightness of the link between 
the spirit and the text explains why saving knowledge is a personal revelation, but not a manifestation of mere 'enthusiasm'.

This middle way was an expression of the Calvinist belief in the 'internal testimony' of the holy spirit - that is, the spirit working in and through the words of scripture on those who were predestined to have justifying faith (though not, of course, on others). This witness was distinct from such 'external' testimony as the judgements of the institutional church, the confirmation offered by miracles and prophecies, and even the text's style and coherence. Because it was in scripture that the holy spirit spoke, the text could be said to be autopistos: self-authenticating (a term originally drawn from Calvin's own discussion). ${ }^{13}$ Although the spirit's message could be seen as 'revelation' - Calvin himself referred to internal testimony as a caelestis revelatio ${ }^{14}$ - the substance of what was revealed had a public character contrasting with the private (because non-scriptural) content of genuinely 'enthusiastic' claims to inspiration. ${ }^{15}$ In an early work directed against Quakers, Bunyan contrasted 'what the Spirit of the Lord bears witness of according to the Scriptures' - that is 'Christ without' - with the nonscriptural 'Christ within' appealed to by Quakers and Ranters. ${ }^{16}$

In the minds of its defenders, the doctrine of the spirit's internal testimony was thus a way of guarding against subjectivism while treating faith as knowledge received direct from God. It was indeed the linchpin of an intellectual structure connecting the public occasion of salvific intervention (the sermon preached on scripture) with the essential privacy of an experience conceived as God's action-in-Man (as opposed to Man's action-supported-by-God). The most careful Restoration defence of Calvin's view (by the leading congregationalist John Owen) presumes that 'Faith Divine' requires a 'Supernatural Illumination' and that 'Supernatural Revelation is the only Objective cause and means of Supernatural Illumination'. ${ }^{17}$ Thus the 'Ministry of the Word' - that is, the puritan sermon on some specific text - was 'the mean which God hath appointed for the Declaration and striking home the 
Testimony which the Holy Spirit gives in the Scripture to its Divine Original'. ${ }^{18}$ Owen was clear that what he was asserting was not the need for supplementary and assisting grace (he thought that 'no Divine, Ancient or Modern, Popish or Protestant' had ever actually denied the need for such assistance). ${ }^{19}$ Rather, he was insisting that faith was of its nature 'an Assent upon Testimony, and consequently Divine Faith is an Assent upon Divine Testimony' ${ }^{20}$ In other words, the distinguishing feature of 'divine faith' was not that it was human faith supported by God's grace, but that it was an assent to God's unmediated witness. He noted, however, that 'some are ready to apprehend that this Retreat unto a Spirit of Revelation, is but a pretence to discard all rational Arguments, and to introduce Enthusiasm into their room. ${ }^{21}$

Such people shared the attitude ascribed to Ignorance. In Owen's more technical language, these were thinkers who rejected the previously orthodox doctrine that the spirit's testimony supplied the 'formal object' of a salvific faith: that is, the object into which such faith must be 'resolved'. ${ }^{22}$ There was, however, no need to put the matter in this way to see that the shift involved a fundamental transformation in the accounts that were usually given of religious practices, and therefore, in the long term, in the kind of power relations that such accounts subverted or supported. When justification was conceived as the transmission of knowledge, the excision of revelation from its position at the heart of the salvific process removed an idea with some obvious subversive potential: God's act-in-Man (which might subvert conventional social order) was being replaced by Man's act-assisted-by-God. As we shall see, the upshot was that the spirit's function of authenticating scripture was taken over by a human 'rational account'. The exercise of reason acquired a new centrality to English Protestant thinking, with consequences that included a distinctive stress on the religious duty of being rational

When seen from this perspective, the combination of ideas ascribed to Ignorance encapsulates a problem of great significance. Ignorance is a fiction, but the purpose of that 
fiction was to describe opinions that were usually held as a package. As we shall see, there are good grounds for thinking that Bunyan had a real individual in mind - an individual, what was more, who was a conscious spokesman for innovative 'latitudinarian' attitudes. In Bunyan's presentation, it is implied that such ideas are widely influential, even, it is suggested, among those thought of by themselves and others as members in good standing of the puritan subculture. Hopeful laments that 'Alas, there are abundance in our Town in his condition; whole Families, yea, whole Streets, (and that of Pilgrims [i.e.puritans] too. ${ }^{23}$ When Ignorance is damned (on the last page of Part One of Pilgrim's Progress), the narrator is made to observe that 'I saw that there was a way to Hell, even from the Gates of Heaven as well as from the City of Destruction '. ${ }^{24}$ This article offers a context that makes sense of his remark, explaining, in particular, how writers of puritan backgrounds came to be hostile towards 'revelations'.

In doing so, it offers an angle of attack on an important problem that is seldom squarely faced. It is not hard to understand the grounds for the rejection of the old theory of imputation. The cost of a theology that emphasises that God's grace is in no way contingent on anything that human beings actually do is a harsh theory of predestination that leaves the decision to save or to reject entirely in God's hands. In other words, abandonment of this theology can fairly be seen as an aspect of the abandonment of Calvinistic theories about predestination in favour of more liberal (loosely 'Arminian') views that based election partly on God's foresight of man's faith (conceived of as a form of independent human effort). One could, however, readily imagine a position that had retained what might be called the informational aspect of ‘internal testimony' alongside an Arminian view of human agency. An adequate account of the history involved must show why this attractive path was not in fact adopted, at least within the mainstream of the Restoration church.

The problem, then, is not so much why Calvinism declined, but why its successor religion, in English circumstances, was generally rationalist and not fideist. A more careful 
and less Whiggish intellectual history would explain this without reference to a rationalist impulse; if the value set on reason is to be the explanandum, it cannot also be the explanans. The analysis presented here seeks to avoid this pitfall. In offering a narrative of the abandonment of the idea that scripture can authenticate itself, it traces a development within theology, that is, within a complex but a rule-bound way of talking that was at home, if anywhere, in universities. The outline of this narrative may seem familiar: it focuses on three writers - Richard Hooker (1564-1600), William Chillingworth (1602-44), and the so-called 'Cambridge Platonist' Benjamin Whichcote (1609-1683) - who play a prominent role in most conventional accounts of English clerical culture's path away from Calvinism. ${ }^{25}$ In each case, however, attention to the theology requires a new account of the interplay of forces from which the enhanced expectations of reason had emerged.

In speaking about Richard Hooker - the natural starting point of any attempt to re-tell this particular story - it is best to begin with a minor and somewhat atypical work: his Learned and comfortable sermon of the certaintie and perpetuitie of faith in the elect. In its present form, the Learned and comfortable sermon is a product of his quarrel with the puritan Walter Travers, who was his fellow-preacher at the Temple Church in London. At the climax of this conflict, in 1586, Travers denounced him to the Privy Council for various allegedly non-Protestant opinions. One such doctrine was Hooker's assertion 'That the assurance of thinges which we beleeve by the word is not so certeyne as of that we perceyve by sense. ${ }^{26}$ Hooker's defence of this idea was simple:

And is it as certeyne? Yea I taughte as I hope he hym selfe I trust woulde not denye that the thinges which God does promyse in his word are surer unto us then any thinge we touche handle or see, but are we so sure and certeyne of them? if we be, 
why does God so often prove his promises unto us as he doth by arguments taken from our own sensible experiences. ${ }^{27}$

In circulating copies of the Learned and comfortable sermon, he was supplying the context of this line of argument.

In making his case he appealed to an established scholastic distinction between 'certainty of evidence' and 'certainty of adherence'. According to Hooker, the former is subjective certitude:

Certainty of evidence wee call that, when the mind doth assent to this or that; not because it is true in it selfe, but because the truth therof is clear, because it is manifest unto us. ${ }^{28}$

In ordinary life, this kind of certainty is common. It is 'evident', for example, that 'a part of any thing is lesse then the whole, the mind is constrayned to say this is true. ${ }^{, 29}$ In 'matters of fayth', however, 'that which wee see by the light of grace...is not to us so evidently certain, as that which sense or the light of nature will not suffer a man to doubt of. ${ }^{30}$ This was the doctrine Travers had complained of. But certainty of adherence is rather different: 'certaintie of adherence is when the hart doth cleave and stick unto that which it doth believe.' ${ }^{31}$ In other words, it has a motivational component: it is the heart's response to the experience of a good.

This certainty of adherence is irremovable:

Even then when the evidence which he hath of the trueth is so small that it greaveth him to feel his weaknes in assenting thereunto; yeat there is in him such a sure adharence to that which he doth but faintly and fearfully believe, that his spirit having once truly tasted the heavenly sweetnes thereof, all the world is not able quite and cleane to remove him from it. ${ }^{32}$

Hooker was well aware that this might cause a pastoral problem: the fainthearted Christian assailed by a doubt would deduce from his present condition that he had never known the heavenly sweetness. But he had a consoling response:

Be it that they are faithles and without beliefe. But are they not greeved with ther unbeliefe?... Whence cometh this but from a secret love and liking which they have of those thinges that are beleeved. No man can love the thinges which in his own opinion are not. And if they thinke those thinges to be which they show that they 
love when they desire to beleeve them; then must it needs be that by desiring to beleev they prove them selves to be true beleevers. ${ }^{33}$

Thus the evidence/adherence distinction did not distinguish certainty that has a rational grounding from certainty produced by other methods, but certainty that is subjectively manifest (whether or not it has a rational grounding) from certainty known from the secret 'love or liking' whose presence is deducible precisely from our doubts. In consequence, it was a basis for a powerful critique of puritan reliance on subjective confidence. Beliefs about one's status are merely 'evidence'; they have nothing to do with 'adherence'. 'Let them beware', Hooker pronounced, 'who challeng to them selves a strength which they have not least they lose the comfortable support of that weaknes which in deed they have. ${ }^{34}$ In a brilliant inversion of conventional ideas, he held that this kind of assurance was incompatible with a theology of imputation: if anyone achieved true certainty of evidence, then he would have a perfect faith that would in turn give rise to a perfect righteousness: 'and then what need wee the righteousness of Christ? his garment is superfluous, wee may be honourably clothed with our owne robes if it be thus. ${ }^{35}$

From the perspective of our larger story about the increasing value set on individual reason, there are thus three points worth noting about this early text. First, it took the commonsensical position that the Bible itself appeals to extra-biblical experience: the sacred text supposes that ordinary 'sensible knowledge' can play some role in bringing the Christian soul to faith. But secondly, it held that this sensible knowledge is at best 'certainty of evidence'; it does not bring us certainty of 'adherence'. Thirdly, it showed that his ideas on this particular question were bound up with commitment to Reformed theology: belief in 'perpetuity of faith in the elect' required his strong distinction between mere 'evidence' (a purely subjective condition which is apt to fluctuate) and 'adherence' (which is altogether irremovable). In other words, the statement that Travers complained of - a downgrading of the force of subjective conviction - is actually connected with the Calvinistic view that no 
regenerate person can lose justifying faith (thus the stock example - David - was still regenerate when he was committing adultery and murder). As it happens, there are good grounds for believing that Hooker was sincere in his attachment to this doctrine. Even in the Dublin fragments, replies to a puritan critic composed at the end of his life, he stuck to the view that all those who will finally be saved have 'perpetuitie of inward grace', that is, that they possess it without any interruption from the moment of their first regeneration. ${ }^{36}$

It is against the background of this sustained commitment to perpetual adherence that one should read Hooker's discussion in the third book Of the lawes of ecclesiastical polity (1593). The Lawes is of course a polemic against those puritans who thought that full instructions for governing the church could readily be found within the Bible. Hooker by contrast argued that there are principles that God has issued for our guidance that are and have to be derived from extra-scriptural sources. As Catholic polemicists had often pointed out, the Bible's own authority looks like a good example. Hooker's carefully-worded discussion of the subject was written in awareness of this Catholic argument and therefore of the importance of not endorsing it. He started by conceding that 'scripture teacheth us that saving truth which God hath discovered unto the world by revelation, and it presumeth us taught otherwise that it self is divine and sacred. ${ }^{37}$ He noted that 'some' (that is, Catholics) maintained that 'to learn [this], we have no other way then onely tradition', and was quite happy to admit that 'the first outward motive leading men so to esteeme of the Scripture is the authority of God's Church. ${ }^{38}$ But this preliminary 'outward motive' was only the beginning of a fairly complex process. When we subsequently 'read or hear the misteries thereof', we find our existing inducement to believe is further strengthened, when 'the very thing hath ministred further reason. ${ }^{39}$ Elsewhere in the Lawes, he characterised human testimony as 'the key which openeth the dore of entrance into the knowledge of scripture', ${ }^{40}$ but the same chapter went on to note (approvingly) that 'that which we have necessary reason for, yea, that which we have seen with 
our eies is not thought so sure as that which the scripture of God teaches. ${ }^{41}$ In other words, he treated human witness as a 'motive' that can at best occasion a superior kind of knowledge.

There was, however, an important role for human reason. Once faith has been established, infidels and atheists may 'give occasion to sift what reason there is, whereby the testimony of the church concerning scripture, and our own persuasion which Scripture itself hath confirmed, may be proved a thing infallible. ${ }^{42}$ Hooker himself appealed to the practice of the Fathers to show that infidels could be confuted 'by arguments such as unbeleevers them selves must needs thinke reasonable, if they judged therof as they should. ${ }^{43}$ But there was nothing here that any Calvinist need deny. As the Dublin fragments put it to his puritan opponents, 'the evidence which good things have for themselves, if reason were diligent to search out, may be soundlie and safely taught without contradiction to any syllable...in those sentences of holy Scripture by you alleged, concerning the actuall disabilitie of reason and will..., $^{44}$

His earliest defender William Covell was thus on firm ground in insisting that the 'scriptures in themselves' have 'inward witnes from that spirit, which is the author of all truth' and that the witness of the church is supplemented by 'the testimony of the Holy-ghost, without which the commendation of the Church were of little value. ${ }^{45}$ Hooker himself was reverently agnostic about the mechanisms through which the spirit worked: even its 'ordinary' operations were 'things secret and undiscernable', though he cautioned against believing or doing 'any certaine particular thing, as being moved thereto by the spirit'. ${ }^{46}$ The closest he came to abandoning internal testimony was to remark that those of his fellow-Protestants who held that 'there is no proof but by the testimony of the spirit' were not intending to exclude 'all force' from human reason, but thought that 'other motives and inducements, be they never so strong and consonant unto reason, are notwithstanding uneffectual in themselves. ${ }^{97}$ In other words, he claimed there was a Protestant consensus that reason could be said to have some 'force' in 
proving scripture, but that the spirit made that force 'effectual'. The ambiguity in this position, which gave rise to developments that he might not have welcomed, was not whether the spirit's testimony was required, but whether its acknowledged role in bringing about adherence was confined to ensuring salvific reception of the truth (as opposed to the active transmission of some kind of knowledge). The same ambiguity surfaced in the thought of William Laud.

Laud's major anti-Catholic work The conference with Fisher (1624; amplified 1639) included a tortured discussion of a complex compound view most notable for insisting that 'the Voyce and Tradition' of the primitive church is 'Divine not aliquo modo, in a sort, but simply'; and therefore that 'the word of God from them, is of like Validity, written, or delivered. ${ }^{48} \mathrm{He}$ conceded that the present church induces attention to scripture, ${ }^{49}$ but he defended Hooker by maintaining that 'the first Inducer to believe is not by and by either the Principall Motive, or the chiefe and last Object of Beliefe. ${ }^{50}$ No one expected reason to prove scripture, but only to 'enable us to disproove that which misguided men conceive against it'. ${ }^{51}$ Thus 'we Resolve [Faith] onely into Prime Tradition Apostolicall, and Scripture itself.' ${ }^{52}$ There were, however, two significant shifts here. Notwithstanding the way that he limited the role assigned to reason, one was that he excluded the spirit's testimony from answering the question 'how the Scripture may be proposed as a credible Object, fit for Beliefe. ${ }^{53}$ The other was the promotion of apostolical tradition to the same status as the text of scripture. But the latter was an obstacle to any tendency to grounding belief primarily in reason; he had no interest, after all, in grounding tradition in reason. Like Covell, Laud insisted that human testimony was only, at most, the occasion for justifying faith. He pointed out that Hooker had described it as 'the Key which opens the doore of entrance into the knowledge of the scriptures' and that this was a different thing from 'the ground of our Beliefe. ${ }^{54}$ In this, as in other respects, he was a very careful thinker who was, for the most part, mindful of a Calvinistic framework even when he was venturing beyond it. ${ }^{55}$ The misunderstanding of Hooker that has since been dominant - 
transforming human witness into more than just a 'motive' - did not become available to people who admired him until those people had themselves abandoned Calvinism.

Perhaps the first and certainly the most significant of those who were willing and able to read Hooker in this way was the culturally pivotal figure of William Chillingworth. Chillingworth's forceful treatise The religion of Protestants (1637) explicitly rejected the old Reformed position: though he pronounced that God might work a 'certainty of adherence, beyond a certainty of evidence', he flatly denied that the former was required for salvation. He went on to reject what he described as 'the false Principle, That it is in vain to believe the Gospel of Christ, with such a kind or belief of assent as they yield to other matters of Tradition. ${ }^{56}$ It was, after all, 'an unreasonable Master, who requires a stronger assent to his conclusions, then his arguments deserve. ${ }^{57}$ To do so was 'to make God a Tyrant, and to say that he requires us certainly to attain that end, for the attaining whereof we have no certain meanes. ${ }^{, 58}$ Moreover, the very idea of a 'perfect rule' implied something 'so evident, that it needs no interpretation'.59 It followed that the necessary credenda were simple propositions that are found within the Bible. The only controversies that the Bible could not settle were those that set out to discover the status of scripture itself, "which cannot be determined but by naturall reason, the only principle, beside Scripture, which is common to Christians. ${ }^{60}$

Chillingworth follows Hooker in the standard narrative. But like Hooker, he has often been poorly understood. In Hooker's case, the usual source of the misunderstanding has been an under-estimate of his Reformed credentials; in Chillingworth's, it is a failure to grasp his personal debt to the new style of churchmanship we know as Laudian. Although he tried the patience of his fellow Laudians, most notably by doubting trinitarian orthodoxy, they 
consistently and rightly understood him as a somewhat deviant ally in what they were trying to do. In particular, he accepted and applauded their ceremonialism, their use of such terms as 'sacrifice' and 'altar', and their tolerance or approval of Arminian departures from the Reformed theology of grace. ${ }^{61}$ At the end of his life, he was also an ardent royalist. Chillingworth was thus the product of a factional milieu whose increasing veneration for the patristic church reflected and encouraged a regard for visible churches; within this culture, the ideal was a reading of the Fathers untainted by Reformed dogmatic systems.

In 1630, Chillingworth dramatically converted from Protestantism to Catholicism. ${ }^{62}$ The letter he wrote to his intimate friend Gilbert Sheldon relied on what had now become a standard argument:

1. Whether it be not evident from Scripture, and Fathers, and Reason; from the goodness of God, and the necessity of Mankind; that there must be some one Church infallible in matters of Faith.

2. Whether there be any other Society of men in the World, besides the Church of Rome, that either can upon good warrant, or at all, challenge to itself the privilege of Infallibility in matter of Faith. ${ }^{63}$

This letter reveals his commitment to two basic premises with which he expected Sheldon at least to sympathise. One is the unsurprising if unCalvinist position that we can deduce from God's goodness that He has made provision even for fallen man to have some realistic chance of finding saving knowledge; the other is the strikingly unProtestant belief that it is a 'society of men' that offers guidance. As we shall see, he never stopped believing either premise.

The outline of his subsequent development is well-known. ${ }^{64}$ After an unsuccessful stay at Douai, he was persuaded to return to England, in part through correspondence with his godfather William Laud. But his preferment in the Church of England was delayed by a number of scruples that still impeded him from re-subscribing to its Articles. The studies that had led him to abandon his belief in the consistency of Roman doctrine had drawn attention to the fact that the pre-Nicene Fathers appeared, if anything, to support the case for Arianism. At the very least, this fact implied that the confident threats of hellfire in the Athanasian creed 
were altogether unacceptable. His brilliantly accomplished anti-Catholic polemic was composed while he was in this intermediate condition. It is famous for maintaining that infallibility requires an infallible foundation. No such infallible grounding could be found for the papists' pretensions. It was, however, possible to reach what he described as a 'moral certainty' of the reliability of scripture.

This biographical story can obviously be read as shaped by an enthusiasm for the power of reason, especially in the light of the contemporary perception that he borrowed from the Socinian Joannes Volkelius. ${ }^{65}$ It is, however, worth noting that Volkelius's position was shaped by a fideist impulse that seems completely foreign to Chillingworth's ideas. Volkelius believed that the evidence available to Christians falls well short of the certainty achieved by mathematics, but that the epistemic gap is to be celebrated. A mathematical certainty has been denied to Christians so as to leave a place for reward and punishment. Thus Christian doctrine functions as a touchstone by which to distinguish the vicious from those of virtuous inclinations. This would not, he believed, be possible 'if we make the truth of Christ's teaching as manifest to all as if it could be be seen by the eyes or fondled by the hands. ${ }^{66}$. At all events, Chillingworth's argument rejected both internal and external testimony. He held that the latter 'may conclude the negative very strongly, to wit, that such a book cannot come from God because it containes irreconcilable contradictions, but the affirmative it cannot conclude, because the contents of a book may be all true, and yet the book not written by divine inspiration. ${ }^{67}$ All that remained was 'the testimony of the Primitive Christians' ${ }^{68}$ He was quite happy to accept 'the Tradition of all ages' as a conclusive answer to all questions he might raise. ${ }^{69}$ Unfortunately, that tradition was exiguous. As he put it in a famous peroration, the study of church history revealed no consensus. On almost every question, there were

Popes against Popes, Councells against Councells, some Fathers against others, the same Fathers against themselves, a consent of Fathers of one age against a consent of Fathers of another age, the Church of one age against the Church of another age. 
Traditive interpretations of scripture are pretended, but there are few or none to be found. No tradition but only of scripture can derive itself from the fountain... ${ }^{70}$

This celebrated passage is not so much, however, an attack upon tradition as a severe insistence that only one tradition - that is, the tradition of scripture - can claim to be certain. A little later, he confirmed that 'Universal, never-failing tradition assures me that [Scripture] was by the admirable supernatural worke of God confirm'd to be the work of God. ${ }^{71}$ If this was a rational judgement, it was no less an assertion of church authority. He soon acquired readers - most notably, perhaps, the puritan leader Richard Baxter - who took it that the tradition to which appeal was made consisted in reports of confirmatory miracles. ${ }^{72}$ But Chillingworth's own argument was probably less crude. He remarked that 'if the doctrine of scripture were not as good...as the Miracles by which it was confirm'd, were great, I should want one main pillar of my faith, and for want of it, I feare should be much stagger'd in it. ${ }^{97}$ Moreover, the debate he was engaged in involved him addressing the problem of defining the canon of scripture. He took it for granted that the status of specific books should be settled by 'the testimonies of the ancient churches'. ${ }^{74}$

When Chillingworth is read against this intellectual background, it become clearer why his work was accepted and rewarded. As we have seen, Laud defended unwritten traditions 'of which kinde this, That the Bookes of Scripture are the Word of God, is the most generall and uniforme. ${ }^{, 75}$ Chillingworth could be taken to be a Laudian who took an eccentrically minimal view of what tradition might prove. In consequence, a Laudian could appreciate his assault on the infallibility of the present church of Rome without dropping the view that the primitive church was, other things being equal, normative. This seems, at all events, to have been the view of Henry Hammond, the intellectual leader of the rigorous conformists during their decades of adversity. ${ }^{76}$ The closest thing to a conformist summa, John Pearson's Exposition of the creed (1659), implicitly rejected the Chillingworthian view, distinguishing 'humane faith' of a Chillingworthian type from the 'divine faith' that responds to scriptural 
revelation. ${ }^{77}$ In the end, it was puritan thinkers who made the idea of a duty to use individual reason a permanent component of the English cultural mainstream.

III

When we turn to Benjamin Whichcote and his famous correspondence with his friend and former tutor Anthony Tuckney, we find ourselves in an altogether different cultural world. The facts are sufficiently striking to deserve some emphasis. During the 1630s, Cambridge politics had been shaped by conflict between Laudian and non-Laudian conformists. During the 1640s, in Cambridge as elsewhere, both of these groups discovered that they were royalists; whatever their opinions about Arminianism, most of the natural leadership of academic Cambridge were loyal both to monarchy and to episcopacy. ${ }^{78}$ In consequence, a relatively small minority - the heirs to the authentic Cambridge puritan tradition of Laurence Chaderton, William Whitaker, William Perkins, and John Preston - was propelled to a position of unchallenged dominance. ${ }^{79}$ The Arminian stronghold of Queens' was left virtually empty, and its fellowship was repopulated from Emmanuel, the college with the strongest living puritan tradition.

This background is important, because prosperity revealed a surprising fact about this little group: it was itself divided and a number of its members - though 'godly' in demeanour and in their politics - were theologically Arminian. Puritanism considered as an identity was combined with a rejection of predestinarian doctrines that earlier puritan thinkers had regarded as essential. At some point between 1644 and 48, the young Simon Patrick (a future bishop of Ely who was then a conventionally godly undergraduate in Queens') confided in his tutor his doubts about

the doctrine of absolute predestination; which I told him always seemed to me very hard, and I could never answer the objections against it, but was advised by divines 
to silence carnal reason. At which he fell a laughing, and told me they were good and sound reasons which I had objected against that doctrine, and made such a representation of the nature of God to me, and of his good-will to men in Christ Jesus, as quite altered my opinion. ${ }^{80}$

The man who did the laughing was not a Laudian, but an ex-fellow of Emmanuel, the highly respected John Smith, a member in good standing of the Westminster Assembly. Together with Ralph Cudworth, Benjamin Whichcote, and Henry More, he has of course been known as a 'Cambridge Platonist', but the label, though defensible, is needlessly distracting. What these figures had in common was a cultural identity that made them politically favourable to parliamentarianism - enough so to accept the posts of their royalist ex-colleagues - combined with increasing commitment to a moralistic standpoint.

This was the local context of the Whichcote-Tuckney letters. Tuckney had been a youthful fellow of Emmanuel during the period in which he had been Whichcote's tutor. He later served as curate to the non-separating congregationalist John Cotton, taking over as incumbent in the church in Boston, England when Cotton moved to Boston, Massachusetts. In due course, he played a significant part in the Westminster Assembly. In 1645, he was a fairly natural choice to be the Master of Emmanuel, though he seems to have stayed in London till 1648, when he was chosen as Vice-Chancellor. ${ }^{81}$ When he returned, he had high hopes, and happy memories of his gifted pupil, having heard that 'when times were very evil, God in his mercie kept your spirit uprighte. ${ }^{82}$ But he was disappointed. In the late 1640 s, in Cambridge as elsewhere, the old theology of imputation was threatened by the emergence of a puritan critique that stigmatised its language as antinomian. ${ }^{83}$ One of the points at issue was the relationship between theology and human reason.

In 1650, things came to a head at Commencement, when Tuckney preached a sermon that in effect defended scholastic procedures against a rising tide of commonsensical literalism and personally disputed about the proposition that 'Articles of faith are not to be constrained to the measure of human reason. ${ }^{94}$ The famous correspondence arose from the next year's 
Commencement, when Whichcote as Vice-Chancellor preached a Commencement sermon, recommending (to quote Tuckney's summary) that 'we wou'd be confined to Scripture words and expressions; in which all parties agree; and not press other forms of words, which are from fallible men. ${ }^{85}$ Tuckney understandably saw this as a personal attack and wrote to his ex-pupil in order to remonstrate. Their correspondence covers many topics. But what is most useful about it, for present purposes, is the insight that it offers into the highly puritan - indeed, in seventeenth-century terms, the 'enthusiastic' spirit - in which Whichcote entertained his new convictions.

Tuckney acknowledged that the roots of Whichcote's attitudes were found within Emmanuel's own culture:

Whilest you were fellow here, you were cast into the companie of very learned and ingenious men; who I fear, at least some of them, studied other authors, more than the scriptures...And hence in part hath runne a veine of doctrine; which divers very learned and able men, whom from my heart I much honour, are, I fear, too much knowen by. - The power of Nature, in Morals, too much advanced - Reason hath too much given to itt, in the mysteries of Faith... ${ }^{86}$

But he suggested Whichcote might also have been swayed by a number of explicitly Arminian influences (including, as it happens, Chillingworth). Whichcote insisted in response that 'trulie I have more read Calvine, and Perkins, and Beza; than all the bookes, authors, or names you mention. ${ }^{97}$ This claim was arguably borne out by the whole character of the position Whichcote was defending. Faced with the menace posed by commonsense Arminianism, it was Tuckney who insisted that it was sometimes necessary to offer 'explications' in forms of words not found within the Bible. ${ }^{88}$ Whichcote replied that he was confident that the plain sense of scripture without human supplement could guarantee a basic orthodoxy. He said that he had used the same interpretative methods in college disputations in 1637 on the charged topic of church government, 'which I wonder', he added, 'that those times should bear and not these. $^{\text {' }} 9$ 
It was, moreover, Whichcote who had the keener sense of the Almighty's providential guidance. In the third of his four letters, he began to lose control, repeatedly and eloquently referring to 'these times' in tones that seem remarkable to anyone accustomed to reading his respectable post-Restoration sermons. He tells us, for example, that 'the times, wherein I live, are more to mee than any else: the workes of God in them which I am to discerne, direct in me both principle affection and action. ${ }^{90}$ Unfortunately, some mistaken people had fallen into what he called a 'spirit of Persecution'

And I do believe; that the destroying of this spirit out of the church is a peece of the Reformation, which God, in these times of changes, aimes-att: and I feare to bee under the power of the anti-character to the work that God is about. ${ }^{91}$

Whichcote's treatment of the question of the authority of scripture was an excellent example of his general approach. At first sight, his assumptions appeared traditional: 'Sacra scriptura est autopistos est Deo digna, est Fide digna: it speaks for itt selfe, it recommends itt selfe to its subject, itt satisfies the reason of the minde; procures its owne enterteinment, by its own excellency. ${ }^{92}$ But it emerged that what he meant by the term autopistos was something wholly different from the Calvinist conception. Thus he held that 'Dignitas et certitudo Christianae religionis are not provable by testimonie of scripture but subsequentlye to the demonstration of the divine authorite of scripture'. ${ }^{93}$ There were in his view three different ways to achieve this demonstration: the quality of the material, the testimony of the spirit, and the deliverances of tradition. As might have been expected, he passed over the claims of tradition in favour of the quality of the material. The radical step that he took was to downgrade the testimony of the Holy Spirit on the grounds that 'though itt bee triumphant, where it is', it is by contrast 'nothing to him that feels itt not'. In other words, what might be thought its most important feature - the purely private character of the experience - was now seen as a reason for denigrating it. Tuckney appealed to 'faith', but Whichcote scornfully responded:

Itt is but humana credulitas, and not fides divina, till I receeve upon divine authoritie: and this I am not negligently to suppose or imagine, but to have it made- 
out to me. For he that beleeves what God saith; without evidence that God saith it; doth not believe God, while hee beleeves the thing that is from God: et eadem ratione si contigisset, Alcorrano Turcico credidisset [for the same reason under other circumstances would have believed the Turkish Koran] and for evidence might have alleged his faith in itt. ${ }^{94}$

It will be observed that 'evidence' has subtly changed its meaning. If 'evidence' is private, it can be understood as a person-specific process of 'making-evident'; if, however, it is public, then it must bear its modern sense of undynamic fact.

The interest and importance of the Whichcote-Tuckney letters is that they cast a light upon a moment of transition. As his rhetoric showed, Whichcote was as 'puritan' as Tuckney; he had worked out his novelties within a godly setting, and they were informed by a loathing of a 'spirit of Persecution'. There can be little doubt that he regarded his position as a development within, not a departure from, the Cambridge puritanism in which he had been trained. In consequence, it is not at all surprising that those who ensured the reception of Chillingworth's ideas were primarily ex-puritans from Cambridge. The next generation was free of the streak of mysticism that characterised the Platonists' high view of human reason, but their most prosaic outlook was equally hostile to notions that smacked of private inspiration. Their cultural puritanism enabled them to ignore the uncongenial features of the Laudian Chillingworth, just as Chillingworth's Arminianism enabled him to ignore the Calvinistic framework of Hooker's argument.

Thus the future archbishop John Tillotson's development was shaped when he came across a copy of The Religion of Protestants. As his funeral sermon recorded, Tillotson's cultural background was wholly puritan. As a fellow of Clare, however, in the early 1650s, he 'happily fell on Chillingworth's book, which gave his mind the ply that it held ever after and put him on a true scent... yet he still stuck to the strictness of life to which he was bred, and retained a just value, and a due tenderness for men of that Persuasion. ${ }^{95}$ But the Restoration version of the Chillingworthian view was most carefully put by the slightly younger Edward 
Stillingfleet. ${ }^{96}$ In 1660, Stillingfleet was 'presbyterian' in the sense that that he defended the moderate puritan case for a more limited episcopacy. ${ }^{97}$ Ten weeks before the ejections of St Bartholomew's Day, he published Origines Sacrae, or a rational account of the grounds of Christian faith, as to the truth and divine authority of the scriptures and the matters therein contained (1662).

As its title indicated, Stillingfleet's famous book was a completion of the process by which the spirit was replaced by a rational account. Though he was keen to emphasise thqat he did not resolve 'all Religion into a meer act of reason and knowledge', he made a sharp distinction between two processes: 'the one is to satisfie man's minde of the truth of the doctrine, the other is to bring them effectually to adhere unto it.' 98 Though he appeased conservatives by stressing that both processes were needed for justification, he had deprived the spirit of the epistemic function that was an essential feature of the Calvinist position. His view of these questions was nonetheless marked by continuities with attitudes presumably derived from his puritan background. Unlike the Laudian Arminians, he tacitly accepted the Calvinistic view that justifying faith is of its very nature 'certain', indignantly rejecting the alternative position that it is 'a meer probable perswasion'.99 In consequence, the concept of 'moral certainty' that he had taken over from Chillingworth's treatise was not understood as a limiting case of probability. Instead, it was regarded as the type of certainty that was appropriate to the situation: 'what', he asked, 'can it be accounted but temerity and imprudence in any to believe a doctrine as true only upon probable inducements? ${ }^{100}$ His nascent ethics of belief was thus in part an outcome of the survival in his thought of puritan commitments. The same can be said of the nature of the central argument of his next major controversial treatise: a Rational account of the grounds of Protestant religion, being a vindication of the Lord Archbishop's relation of a conference (1665). His defence of Laud's Relation may well have been sincere, but it involved ignoring Laud's stress upon the church, transforming Laud's 
discussion of 'the ground of our Beliefe' - in which reason's role was modest and fairly marginal - into a defence of the 'rational credibility' of scripture. ${ }^{101}$

The personal trajectory of men like Stillingfleet had given them a message that was not available to colleagues who emerged from mainstream conformity. Without obvious exception, these 'latitudinarians' were men of godly backgrounds who had held benefices in interregnum times. ${ }^{102}$ Even those of them who were ordained by bishops were liable to be classified as being 'presbyterians' rather than 'cavaliers' (where presbyterian refers to an identity to which views on church government were largely incidental). In other words, they fell upon the parliamentarian side of what was primarily a political divide produced by the sidetaking of the first Civil War. Simon Patrick, for example, continued to be regarded as 'presbyterian' long after he had taken the risk of getting episcopal orders ${ }^{103}$ - a detail that would obviously have special interest if he were the 'S.P.' who wrote A brief account of the new sect of latitude-men (1662).

The presence of such people in the Restoration church was one of the main reasons for its stability, especially when confronted with the Stuart preference for toleration for Catholicism. Although they favoured charity to moderate nonconformists - often though not invariably involving 'comprehension' - they had no real sympathy with outright toleration. Moreover, their minimisation both of the sacraments ${ }^{104}$ and Christianity's dogmatic content contracted the sphere where the needs of the church might conflict with royal power. Above all, they rejected Calvinist predestination. Their background had left them ideally placed to take from Chillingworth the basis of a simplified and moralistic gospel that had an appeal to laymen who were positively hostile to the traditional puritan subculture. ${ }^{105}$ At all events, the 'latitude' of which they were accused was at first an accusation from a puritan perspective. ${ }^{106}$

No public figure better exemplified this point than Edward Fowler, minister of Northill outside Bedford, who held both the views that Bunyan ascribed to Ignorance. Fowler's 
religious background was unquestionably godly; his father and his brother were ejected from their livings in 1662, and he himself had briefly refused conformity. Theologically, however, he was a keen supporter of the innovative party. Although, he obtained his first degree at Oxford, he later moved to Cambridge. It was under Cambridge influence that he wrote a wellknown book: The principles and practice of certain moderate divines of the Church of England (1670). In a manuscript note on his copy, the Calvinistic Oxford academic Thomas Barlow remarked that 'this discourse is a Justification of a Latitudinarian (the word was hatch'd at Cambridge, and there you may heare more of it) against the zealous non-Conformists. ${ }^{107}$ This was a reasonable summary: the criticisms that Fowler was anxious to rebut were virtually all ones that might be made by nonconformists. Moreover, he defended both of the heresies that Bunyan subsequently ascribed to Ignorance. He rejected imputation of Christ's works (as opposed to Christ's merits) $)^{108}$ and criticised those who made use of an 'internal testimony, or a secret powerful persuasion wrought immediately in the soul of men' as a proof of the authority of scripture. In Fowler's view, this was 'as gross a Circle as that we accuse the papists of. For as they prove the scriptures by their Church, and their Church by the Scriptures; so these prove the Scriptures by this testimony of the Holy Ghost, but then cannot prove so much as that there is any such person, but by the Scriptures. ${ }^{109}$

The following year, he expanded and developed his position in a work whose central thesis is expressed in its full title: The design of Christianity; or, a plain demonstration and improvement of this proposition, viz. That the enduing men with inward real righteousness or true holiness, was the ultimate end of our Saviour's coming into the world, and is the great intendment of his blessed gospel (1671). But though this was his central theme, he did not fail to mention that 'for our satisfaction whether the Holy Scriptures are Divinely inspired, it is necessary that we employ our Reason', on pain of having 'no better bottome for our belief of the Bible, that the Turks have for theirs of the Alcoran' ${ }^{110}$ 
Bunyan felt moved to publish a more or less instant riposte: A defence of the doctrine of justification by faith in Christ Jesus (1671). The substance of this tract, proudly dated 'From Prison', was a vigorous re-statement of the centrality of justification achieved by imputation. Fowler's position was assailed for neglecting the fact that the holiness that inheres in human nature 'is not the righteousness that justifieth us before God from the curse.' 111 But Bunyan also noted that it was necessary that 'those that follow Jesus in his Spirit, must first receive that Spirit from Heaven.'. This spirit was received by 'applying the Merits of Christ' and not 'by the Works of the Law, but by the hearing of Faith', not 'in the Ministry or Doctrine of Morals, but in and by the Ministry of Faith', that is, in and by sermons. ${ }^{112}$ Fowler had gone wrong in 'contenting your self to rest within the confines of the humane Nature, acts of reason, as men or Creatures only'. ${ }^{113}$ The book was 'begun in Ignorance, mannaged with Errour, and ended in Blasphemy.' 114

From Bunyan's perspective, though, Fowler was worse than ignorant; he was an exemplification of shifts in attitude in people who had recently been culturally godly. Bunyan regarded Fowler as a 'glorious Latitudinarian, that can, as to Religion, turn and twist like an Eel on the Angle.' 115 He was sorry that there were 'so many that have done Violence to their former Light' and 'made Shipwrack of their former Faith'. Though the two men were not personally acquainted, 'yet I have heard as if Blood might pursue you, for your unstable Weathercock Spirit.' ${ }^{116}$ Bunyan thus thought of Fowler as a recent apostate. It is easy to see why he did so. Fowler's continuing puritan credentials are shown by the fact that Richard Baxter wrote in his defence. ${ }^{117} \mathrm{He}$ went on to become rector of the great puritan parish of St Giles Cripplegate and worked to frustrate coercion against moderate dissent. As late as 1679, in his position as holder of a canonry at Gloucester, he organised the smashing of a cathedral window that he regarded as idolatrous. ${ }^{118}$ After the Revolution, he took the radical view that William and Mary should be seen as conquerors, whose 'right' had been derived from their 
'Success in a just War', though 'the assuming of it was not by any ways of force or violence, but by a Free Consent of the People'. ${ }^{119}$ In all these respects, his behaviour betrayed his cultural background.

IV

By the time of Pilgrim's Progress, rejection of the testimony of the holy spirit was rapidly solidifying into common sense. The idea of a self-evidencing scriptural revelation had ceased to be an aspect of a theory of faith, becoming instead a pathology of theories of knowledge. John Locke said little that somebody like Fowler could object to in holding, in a chapter about 'Enthusiasm', that 'Revelation is natural Reason enlarged by a new set of Discoveries communicated by God immediately, which Reason vouches the Truth of, by the Testimony and Proofs it gives, that they come from God '. ${ }^{120}$ In the long term, this position was plainly vulnerable to people who doubted that rational proofs could rest on miracles. Fowler himself lived long enough to write a shocked response to Locke's pupil Shaftesbury's comment that to claim 'moral certainty' about a miracle was actually itself a symptom of 'enthusiasm'. ${ }^{121}$ But the theoretical weakness of his rational religion - the fact that it gave rise to an ethics of belief that generated tests it was unlikely to survive - should not distract attention from its practical robustness.

The assumptions that faith must admit of a 'rational account' and that evidence, of its nature, had a public character lay somewhere near the heart of a new cultural politics that was to prove both stable and longlasting. Though the chronology suggests that this was in part a reaction to the supposed 'enthusiasm' of the Revolution, it was not primarily a royalist reaction. The key to the transition was that the crucial step was largely the work of divines who set out from a culturally puritan standpoint. Precisely because they came from the parliamentarian- 
presbyterian as opposed to the cavalier-episcopalian side of England's fundamental political cleavage, their message was ideally pitched to win mainstream acceptance. The result was a re-drawing of the perimeter within which educated forms of discourse were conducted, with consequences including the fruitful prejudice in favour of ideas that could be publicly established that played some role in Royal Society science. ${ }^{122}$ As Bunyan found, re-statements of previously orthodox views were not so much refuted as excluded from discussion; Fowler's response to Bunyan's old-fashioned arguments had the dismissiveness implied by its title: Dirt wip't off (1672). ${ }^{123}$ The social stability promised by this development no doubt in part accounts for its popularity. But the dramatic change had intellectual preconditions. At each stage of the history this article describes, books were absorbed by readers who were largely ignorant of the presuppositions of their authors. Stillingfleet's basic outlook was as far from Chillingworth's as Chillingworth's had been from Richard Hooker's. The misapprehensions resulting were creative in effect, but they were also symptoms of the contingency that underlay the history of the value set on reason.

\footnotetext{
${ }^{1}$ John Bunyan, The pilgrim's progress from this world to that which is to come, London 1678 (Wing B.5557), 162.

${ }^{2}$ See for instance the views attributed to 'Asunetos' (described on p.1 as 'an ignorant man') in Arthur Dent, A plaine man's path-way to heaven, London 1601 (RSTC 6626), 18-19. For Bunyan's familiarity with Dent, see Bunyan, Grace abounding to the chief of sinners, London 1666 (Wing B.5523), 4.

${ }^{3}$ Bunyan, Pilgrim's progress, 204.

${ }^{4}$ Bunyan, Grace abounding, 10.

${ }^{5}$ Bunyan, Pilgrim's progress, 205.
} 
6 ، ...erit scilicet Justificatio ex operibus, quanquam sine operum merito ...hoc praecipuum [est], \& omnium maxime populare Adversariorum latibulum' (Thomas Tully, Justificatio Paulina, Oxford 1674 (Wing T.3244), 44).

${ }^{7}$ Quoted in Bunyan, A defence of the doctrine of justification by faith in Jesus Christ, 1672 (Wing B.5507), 113.

${ }^{8}$ For the classic exposition of this point, see C.F.Allison, The rise of moralism: the proclamation of the gospel from Hooker to Baxter, New York 1966.

${ }^{9}$ Bunyan, Pilgrim's progress, 206.

${ }^{10}$ Bunyan, Pilgrim's progress, 206.

${ }^{11}$ Bunyan, Pilgrim's progress, 207.

${ }^{12}$ Bunyan, Grace abounding, 33.

${ }^{13}$ On the emergence of the concept, see Henk van den Belt, The authority of scripture in Reformed theology: truth and trust, Leyden 2008. The fullest English discussion is William Whitaker, Disputatio de sacra scriptura, London 1588 (RSTC 25366). For a semi-popular English-language account from Bunyan's generation, see Thomas Ford, Logos autopistos, or, Scriptures self-evidence, London 1667 (Wing F.1514).

${ }^{14}$ Jean Calvin, Institutio Christianae Religionis, Geneva 1559, Book I, Chapter vii, Paragraph 5.

15 John Owen, Of the divine originall, authority, self-evidencing light and power of the scripture, Oxford 1659 (Wing 0.784), 90-91.

${ }^{16}$ John Bunyan, A vindication of the book called, some gospel-truths opened, London 1657

(Wing B.5606), 38.

${ }^{17}$ John Owen, The reason of faith, London 1677 (Wing 0.801), 2.

${ }^{18}$ Owen, Reason of faith, 114.

${ }^{19}$ Owen, Reason of faith, 171.

${ }^{20}$ Owen, Reason of faith, 146-7.

${ }^{21}$ Owen, Reason of faith, 90.

22 Owen, Reason of faith, 81.

${ }^{23}$ Bunyan, Pilgrim's progress, 209.

24 Bunyan, Pilgrim's progress, 232.

${ }^{25}$ For a sense of the stability of the standard narrative, compare the chapter structure of John Tulloch, Rational theology and Christian philosophy in England in the seventeenth century, 2 vols, Edinburgh 1872, with that of (e.g.) F.C.Beiser, The sovereignty of reason: the defense of rationality in the early English Enlightenment, Princeton 1996.

${ }^{26}$ The Folger Library edition of the works of Richard Hooker, ed.W.Speed Hill, 8 vols, Harvard 1977-98, v. 236.

${ }^{27}$ Hooker, Works, v. 236.

${ }^{28}$ Hooker, Works, v. 70.

${ }^{29}$ Hooker, Works, v. 70.

${ }^{30}$ Hooker, Works, v. 70.

${ }^{31}$ Hooker, Works, v. 70-1.

${ }^{32}$ Hooker, Works, v. 71.

${ }^{33}$ Hooker, Works, v. 76.

${ }^{34}$ Hooker, Works, v. 71-2.

${ }^{35}$ Hooker, Works, v. 71.

${ }^{36}$ Hooker, Works, iv. 163.

${ }^{37}$ Hooker, Works, i. 231.

${ }^{38}$ Hooker, Works, i. 231.

${ }^{39}$ Hooker, Works, i. 231.

${ }^{40}$ Hooker, Works, i. 177. 
${ }^{41}$ Hooker, Works, i. 179.

${ }^{42}$ Hooker, Works, i. 231.

${ }^{43}$ Hooker, Works, i. 232.

${ }^{44}$ Hooker, Works, iv. 108-9.

${ }^{45}$ William Covell, A just and temperate defence of the five books of ecclesiastical policie, London 1603 (RSTC 5881), 27, 29 (wrongly paginated 29, 25). For another view, see JeanLouis Quantin, The Church of England and Christian antiquity: the construction of a confessional identity in the 17th century, Oxford 2009, 93-4.

${ }^{46}$ Hooker, Works, i. 232-3.

${ }^{47}$ Hooker, Works, i. 232.

${ }^{48}$ William Laud, A relation of the conference between William Lawd...And Mr Fisher the Jesuite, London 1639 (RSTC 15298), 81.

${ }^{49}$ Laud, Relation, 81.

${ }^{50}$ Laud, Relation, 82.

${ }^{51}$ Laud, Relation, 80.

${ }^{52}$ Laud, Relation, 85.

${ }^{53}$ Laud, Relation, 80.

${ }^{54}$ Laud, Relation, 89.

${ }^{55}$ On this theme, see Alan Cromartie, 'The mind of William Laud', in England's wars of religion, revived, ed.Charles W.A.Prior and Glenn Burgess, Farnham 2011, 75-100.

${ }^{56}$ William Chillingworth, The religion of Protestants a safe way to salvation, Oxford 1638 (RSTC 5138), 37.

${ }^{57}$ Chillingworth, Religion, Preface, section 2.

${ }^{58}$ Chillingworth, Religion, 92.

${ }^{59}$ Chillingworth, Religion, 54.

${ }^{60}$ Chillingworth, Religion, 53.

${ }^{61}$ Chillingworth, Religion, Preface, sections 20-26.

62 On Chillingworth's motives for converting and also (probably) for re-converting, see the important clarification by Quantin, Christian antiquity, 213-15. The question of the degree of weight that Chillingworth attributed to the Fathers is connected the question of the relationship between his Religion of Protestants and his close friend Viscount Falkland's 'A discourse of infallibility' (elaborately defended in Falkland, A discourse of infallibility with an answer to it: and his lordship's reply, London 1651 (Wing F.317). For apparent concessions of the utility of patristic study, see Falkland, Discourse, sig.cv and p.180. Falkland's attitudes were probably affected by his appeal to the early Fathers to give respectability to his Arminianism (Discourse, sig.c2v and pp.108-9; Quantin, Christian antiquity, 218).

${ }^{63}$ Pierre Des Maizeaux, An historical and critical account of the life and writings of William Chillingworth, London 1725, 8.

${ }^{64}$ Warren Chernaik, 'Chillingworth, William' in ODNB.

${ }^{65}$ Sarah Mortimer, Reason and religion in the English revolution: the challenge of

Socinianism, Cambridge 2010, 68

${ }_{66}$ 'Si veritatem disciplinae Christi ita omnibus manifestam esse volumus, ut oculis cerni, manibusque contrectari possit' Joannes Volkelius, De vera religione libri quinque, Racoviae, 1630, Book V, 377).

${ }^{67}$ Chillingworth, Religion, Preface, section 13.

${ }^{68}$ Chillingworth, Religion, Preface, section 13.

${ }^{69}$ Chillingworth, Religion, 85.

${ }^{70}$ Chillingworth, Religion, 376.

${ }^{71}$ Chillingworth, Religion, 379. 
72 The Chillingworthian argument of Richard Baxter, Addition to the saints everlasting rest, to be put before the first part, London1651 (Wing B.1180B), appeals exclusively to miracles.

${ }^{73}$ Chillingworth, Religion, 69.

${ }^{74}$ Chillingworth, Religion, 63.

${ }^{75}$ Laud, Relation, 81.

${ }^{76}$ For acute remarks on Hammond's efforts to minimise the implications of Chillingworth's ideas, see Quantin, Christian antiquity, 269-73. It is notable that Hammond's principal contribution to this debate took the form of a defence of the more patristically-minded Falkland: Henry Hammond, A view of some exceptions which have been made by a Romanist to the Lord Viscount Falkland's Discourse of the infallibilitie of the Church of Rome, Oxford 1646 (Wing H.609).

${ }^{77}$ John Pearson, An exposition of the creed, London 1659 (Wing P.995), 7-9

${ }^{78}$ For their own account of what followed, see Querela Cantabrigiensis, Cambridge 1647

(Wing B.1010).

${ }^{79}$ The best introduction is still the Preface to 'Eight letters of Anthony Tuckney, and Dr Benjamin Whichcote', printed as an appendix to Benjamin Whichcote, Moral and religious aphorisms, ed. Samuel Salter, London 1753.

${ }^{80}$ The works of Symon Patrick, ed. Alexander Taylor, 9 vols, Oxford 1858, ix. 419.

${ }^{81}$ Patrick Collinson, 'Tuckney, Anthony' in ODNB.

${ }^{82}$ Whichcote, 'Letters', 37.

${ }^{83}$ For a very public statement, addressed to a conservative but puritan House of Commons, see Ralph Cudworth, A sermon preached before the honourable House of Commons, Cambridge 1647 (Wing C.7469).

${ }^{84}$ Whichcote, 'Letters', 9n.

${ }^{85}$ Whichcote, 'Letters', 2.

${ }^{86}$ Whichcote, 'Letters', 38.

${ }^{87}$ Whichcote, 'Letters', 54.

${ }^{88}$ Whichcote, 'Letters', 24-5.

${ }^{89}$ Whichcote, 'Letters', 12

${ }^{90}$ Whichcote, 'Letters', 115.

${ }^{91}$ Whichcote, 'Letters', 116.

${ }^{92}$ Whichcote, 'Letters', 48

${ }^{93}$ Whichcote, 'Letters', 110.

${ }^{94}$ Whichcote, 'Letters', 111-12.

${ }^{95}$ Gilbert Burnet, A sermon preached at the funeral of the most reverend Father in God John Lord Archbishop of Canterbury, London 1694 (Wing B.5902), 11.

${ }^{96}$ For Tillotson's debt to Stillingfleet, see John Tillotson, The rule of faith, London 1666 (Wing T.1218), Ep.Ded.

${ }^{97}$ In the first edition of his Irenicum, London 1660 (Wing S.5596), when he was Rector of Sutton (a benefice to which he was appointed by the presbyterian Sir Roger Burgoyne). For unkind contemporary comment on his later change of heart, see John Barret, The rector of Sutton committed with the dean of St Paul's, London 1680 (Wing B.910A), and Vincent Alsop, A reply to the reverend Dean of St Paul's reflections on the rector of Sutton, London 1681 (Wing B.2919).

${ }^{98}$ Stillingfleet, Origines sacrae, 250-51.

${ }^{99}$ Stillingfleet, Origines, 247. Contrast Chillingworth's appeal to 'the highest degree of probability' at Religion, 224.

${ }^{100}$ Stillingfleet, Origines, 246.

${ }^{101}$ Edward Stillingfleet, A rational account of the grounds of Protestant religion, London 1664 (Wing S.5624), 202-34. 
${ }^{102}$ For a useful list of names, see John Spurr, "Latitudinarianism" and the Restoration church', Historical journal 31, 1988), 69. Spurr's article is a fine account of how they presented themselves, neglecting (as they did themselves) their godly origins.

${ }^{103}$ Patrick, Works, ix. 480-1. For helpful remarks on the use of the term 'presbyterian', see

Roger Morrice and the puritan Whigs: the Entring Book of Roger Morrice 1677-91, ed. Mark Goldie, 7 vols (Woodbridge: Boydell and Brewer, 2009), i. 149-61.

${ }^{104}$ Confusingly, some of them favoured frequent communion (Spurr, 'Latitudinarianism', 179), but this was a mark of their retreat from Calvin's theory of 'spiritual presence', in part under the influence of Cudworth's A discourse concerning the true nature of the Lord's Supper, London 1642 (Wing C.7466), described by Joseph Glanvill as identifying 'the genuine notion of the Sacrament' (J.I.Cope, "The Cupri-Cosmits": Glanvill on latitudinarian anti-enthusiasm', Huntington Library Quarterly 17 (1954), 274). Frequent reception was desirable precisely because the object of the communion service was barely distinct from psychological reinforcement.

${ }^{105}$ It is instructive to read through the twenty accounts of sermons that were preached by Tillotson in The diary of John Evelyn, ed.E.S.De Beer, 6 vols, Oxford 1955, iv. and v. When Pepys first heard a sermon by Edward Stillingfleet, he found himself astonished by its religious power: 'the most plain, honest, good, grave sermon, in the most unconcerned and easy yet substantial manner, that ever I heard in my life' (The diary of Samuel Pepys, ed. Roger Latham, 11 vols, London 1970-83, vi. 87). He later devoted a day with a friend to 'reading and discoursing over part of Mr Stillingfleete's Origines sacrae, wherein many things are very good - and some frivolous' (vi. 297).

${ }^{106}$ Spurr, 'Latitudinarianism', 62-4.

${ }^{107}$ Noted in ODNB. Barlow's copy is the one available on Early English Books Online.

${ }^{108}$ Edward Fowler, The principles and practices of certain moderate divines of the Church of England (greatly mis-understood) truly represented and defended, London 1670 (Wing F.1711), 166.

${ }^{109}$ Fowler, Principles, 55.

${ }^{110}$ Fowler, The design of Christianity, London 1671 (Wing F.1698), 137.

${ }^{111}$ Bunyan, Defence, 13. This is the implied accusation that Ignorance responds to at n.4 above.

112 Bunyan, Defence, 109.

${ }^{113}$ Bunyan, Defence, 7.

${ }_{114}$ Bunyan, Defence, 111.

${ }^{115}$ Bunyan, Defence, 91.

${ }^{116}$ Bunyan, Defence, 73.

${ }^{117}$ Richard Baxter, How far holinesse is the design of Christianity, London 1671 (Wing

B.1282); N.H.Keeble and G.F.Nuttall, A calendar of the correspondence of Richard Baxter, 2 vols, Oxford 1991, vol.II, 116-17, 122-3, 124.

${ }^{118}$ For these biographical details, see John Spurr, 'Fowler, Edward' in ODNB.

119 [Edward Fowler], An answer to the paper delivered by Mr Ashton at his execution, London 1690 (Wing F.1695), 23. For the same position with some differences of emphasis, see also [Edward Fowler], A vindication of the divines of the Church of England, who have sworn allegiance to K.William and Q.Mary, London 1689 (Wing F.1728).

${ }^{120}$ John Locke, An essay concerning human understanding, ed.Peter Nidditch, Oxford 1975, 698.

${ }^{121}$ Edward Fowler, Reflections on a letter concerning enthusiasm, London 1709, 61.

${ }^{122}$ This bears upon the prominence of latitudinarians in Royal Society science detected, for example, by Barbara Shapiro ('Science, politics, and religion', Past and present 66 (1975), 133-8). 
${ }^{123}$ Dirt wip't off, or, a manifest discovery of the gross ignorance, erroneousness, and most unchristian and wicked spirit of one John Bunyan, London 1672 (Wing F.1701). 